\title{
Coating of glass with tetra-cationic porphyrin and its zinc compound used as photo- inactivation of bacteria
}

\author{
Rahmatollah Rahimi*, Fatemeh Fayyaz ${ }^{a}$, Mehdi Rassa ${ }^{b}$ \\ ${ }^{a}$ Department of Chemistry, Iran University of Science and Technology, Narmak, Tehran, 16846-13114, Iran \\ ${ }^{b}$ Department of Biology, Faculty of Science, Guilan University, Rasht, Iran \\ *Corresponding author E-mail address: rahimi rah@iust.ac.ir \\ Tel: +98-21-77240290 Fax: +98-21-77491204
}

\begin{abstract}
The meso-tetrakis (4-N, N, N-trimethylanilinium) porphyrin and its zinc compound deposited on glass slide at high temperature and at a pressure of 15 PSI were used as photo-inactivation surface. Also, the effect of two porphyrin compounds irradiated with tungsten lamp, on a Gram negative bacterium, Pseudomonas aeruginosa, and a Gram positive bacterium, Bacillus subtilis was investigated.
\end{abstract}

Keywords: Pseudomonas aeruginosa; Bacillus subtilis; Photo-inactivation; Tetra-cationic porphyrin.

\section{Introduction}

Severe health hazards and diseases can be concluded by the adhesion and propagation of bacteria on the surfaces of various compounds [1]. In recent years, preparation of materials with antibacterial properties, for use in a wide range of fields such as sanitary materials, food packaging, household, medical, and military items has grown. Antimicrobial surfaces can be created by incorporating antimicrobial types via interaction covalent bonding or non-covalent to the surface [2].

Photo-sensitizers (PS) such as porphyrin compounds have been intensively studied for their use as photobactericidal agents in photodynamic antimicrobial chemotherapy (PACT) against Gram negative and Gram positive bacteria [3-8]. PACT relies on the accumulation of a photosensitizing agent intra-cellular and illumination with visible light. The photodynamic process involves energy absorption by the photo-sensitizer which, brought to its excited triplet state, either activates ground state molecular oxygen into singlet oxygen or generates free radicals. Photo-toxicity primarily relies on the formation of singlet oxygen $\left({ }^{1} \mathrm{O}_{2}\right)$ after 
illumination. This highly reactive species is able to react with almost every cellular component, bringing about irreversible damage that ultimately leads to cell death [1]. This technique has recently been studied against a wide range of bacteria, fungi, yeasts and viruses that can cause serious clinical problems [9-13].

The effect of meso-substituted cationic porphyrins has been investigated on Gram negative and Gram positive bacteria [3, 13-16]. For example, photodynamic treatment of $\mathrm{N}$-alkyl-pyridyl porphyrins has been used on various bacteria using different light sources [5-7, 17].

Our aim of present work is to investigate the effect of tetrakis (4-N, N, N-trimethylanilinium) porphyrin and its zinc metal ion on the photo-inactivation of $P$. aeruginosa and B. subtilis by means of an irradiation source of visible light. Also, coating of these compounds on the glass slides can be used as a surface with photoinactivation properties.

\section{Materials and methods}

All of the used chemicals in this work were purchased from Merck and used without further purification. Gram positive bacterium $B$. subtlis, and Gram negative bacterium $P$. aeruginosa were obtained from the microbiology laboratory of Guilan University. Electronic spectra were measured on a UV-1700 pharma Spec (Shimadzu) with a quartz cuvette. A 100 Watt tungsten lamp was used as light source. To absorb heat, plate filled water was used. The wavelength range for the lamp was approximately 400-800 $\mathrm{nm}$.

\section{Preparation porphyrin and coating on glass}

The porphyrin, tetrakis (4-N, N, N-trimethylanilinium) porphyrin (TAPP) and its zinc ion complex (ZnTAPP) were synthesized as reported previously [18-21]. A stock solution of porphyrins was prepared in water at concentration $2 \times 10^{-3} \mathrm{M}$ and glass slides $(1 \times 1 \mathrm{~cm})$ was immersed in it. These samples were placed in an autoclave at temperature $121^{\circ} \mathrm{C}$ and at a pressure of 15 PSI for a period of time. Then glass slides removed and washed with water until no porphyrin could be detected in the supernatant by UV-visible spectrophotometer.

\section{Antibacterial activity of photosensitive glass}

Gram-positive bacterium, B.subtilis and Gram-negative bacterium, $P$. aeruginosa were inoculated into nutrient broth and incubated at $37{ }^{\circ} \mathrm{C}$ overnight under aerobic conditions. The stock suspensions were diluted to give a working suspension of approximately $10^{7}-10^{8}$ colony forming units/mL (CFU/mL). Amount of broth culture was aseptically transferred onto nutrient agar plates and spread on the surface with a sterile spreader. A stock solution of porphyrins was prepared in water at various concentrations. Wells (diameter $0.5 \mathrm{~cm}$ ) were made in nutrient agar seeded with the target strain. Aliquots of different concentrations of porphyrins were added to these wells. The plates were incubated at $37^{\circ} \mathrm{C}$ for a few minutes in the dark and illuminated with the tungsten 
lamp for 30 minutes. They were then incubated at $37^{\circ} \mathrm{C}$ overnight in the dark. One well was filled with water in the same conditions, as negative control. Bacterial growth was examined visually by measuring inhibition zones around the wells. A diameter larger than $10 \mathrm{~mm}$ was considered as a positive response formally.

For photo-bactericidal test of porphyrins coated on glass slides, the samples were cut $(1 \times 1 \mathrm{~cm})$ and put on the inoculated Petri dish aseptically. For negative control, one plate was untreated glass slide. The former method was used for Inhibition zones around the samples. We illuminated the samples for 90 min. Each sample was removed and transferred into sterile water. After gentle stirring at $37^{\circ} \mathrm{C}$, serial dilutions of these suspensions were prepared. Aliquots $(100 \mu \mathrm{l})$ of diluted samples were then spread on nutrient agar plates. After incubation at $37{ }^{\circ} \mathrm{C}$ for $24-48 \mathrm{~h}$, plates were examined and the number of CFU was counted manually. Each test was done in triplicate.

\section{Results and discussion}

The absorption spectra of two porphyrin compounds were recorded in $\mathrm{H}_{2} \mathrm{O}$ (Figure 1). The absorption spectrum of TAPP and ZnTAPP, exhibit a Soret and Q bands at 412, 515, 552, 580, $634 \mathrm{~nm}$ and 421, 556, $596 \mathrm{~nm}$ respectively.

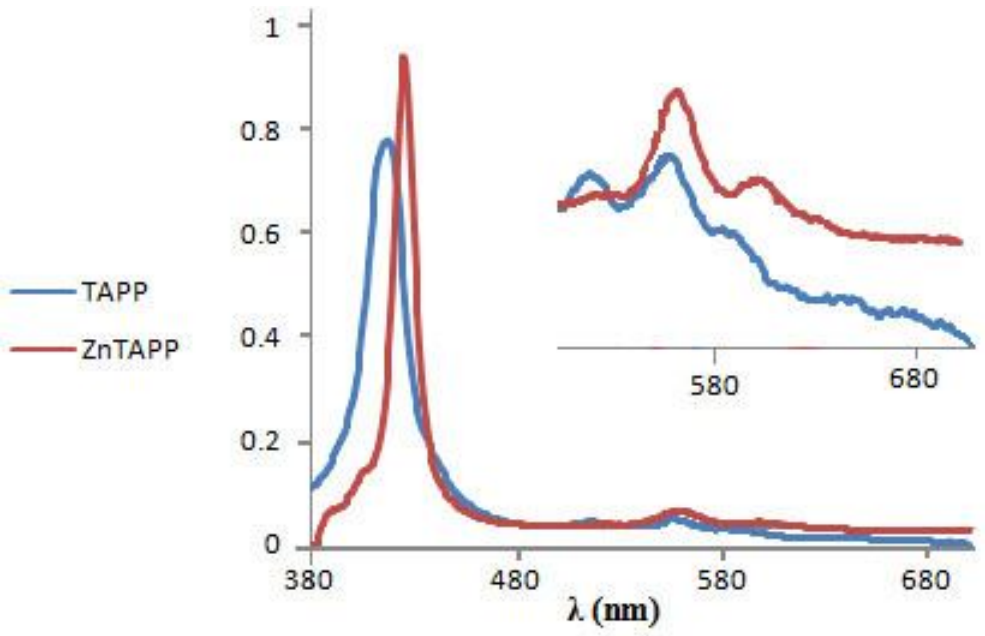

Figure1. The UV-Vis spectra of TAPP and ZnTAPP in water

The effect of various concentrations of TAPP, ZnTAPP and coating of glass with them against two strains of bacteria on agar surface, are shown in Table 1 and 2 . Inhibition zones larger than $10 \mathrm{~mm}$ were considered as a positive response formally. Photographs of the coating of glass with TAPP, ZnTAPP and inhibition zones for these samples were shown in figures 2 and 3. We illuminated coating of glass for $90 \mathrm{~min}$, because exposure time for $30 \mathrm{~min}$ was not effective enough. Probably, it can be attributed to trace porphyrins attached to glass. The optimum concentration of TAPP and ZnTAPP for P. aeruginosa, was $60 \mu \mathrm{g}$ per milliliter. At this concentration 
colony number decreased by $\sim 3.7 \operatorname{logs}$ and $\sim 3.42$ logs respectively. For B. subtilis, at higher concentrations of $15 \mu \mathrm{g}$ per milliliter, no colonies were observed.

Table1. Inhibition zones of various concentrations of TAPP and ZnTAPP on selected strains

\begin{tabular}{c|ccc}
\hline \multirow{2}{*}{ Sample } & $\begin{array}{c}\text { Concentration } \\
(\mu \mathrm{g} / \text { well })\end{array}$ & $\begin{array}{c}\text { Diameter of inhibition } \\
\text { zone }(\mathrm{mm}) \\
\text { P. aeruginosa }\end{array}$ & $\begin{array}{c}\text { Diameter of inhibition } \\
\text { zone }(\mathrm{mm}) \\
\text { B. subtilis }\end{array}$ \\
\hline \multirow{3}{*}{ TAPP } & 60 & 10 & 11 \\
& 30 & 6 & 9 \\
& 10 & 6 & 7 \\
& & & 12 \\
& 60 & 10 & 10 \\
& 30 & 6 & 8
\end{tabular}

Table2. Inhibition zones of Coating glass with TAPP and ZnTAPP on selected strains

\begin{tabular}{c|c|c}
\hline Sample & $\begin{array}{c}\text { Diameter of inhibition zone (mm) } \\
\text { P. aeruginosa }\end{array}$ & $\begin{array}{c}\text { Diameter of inhibition zone (mm) } \\
\text { B. subtilis }\end{array}$ \\
\hline Coating glass with TAPP & 48 & 49 \\
Coating glass with ZnTAPP & 42 & 43
\end{tabular}

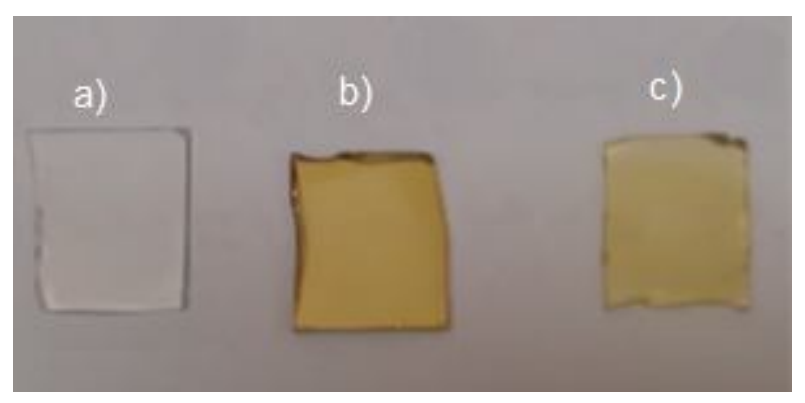

Figure2. Photographs of (a) untreated glass slide; (b) treated glass slide with $\mathrm{TAPP}^{4+}$ and (c) treated glass slide with $\mathrm{ZnTAPP}^{4+}$ 

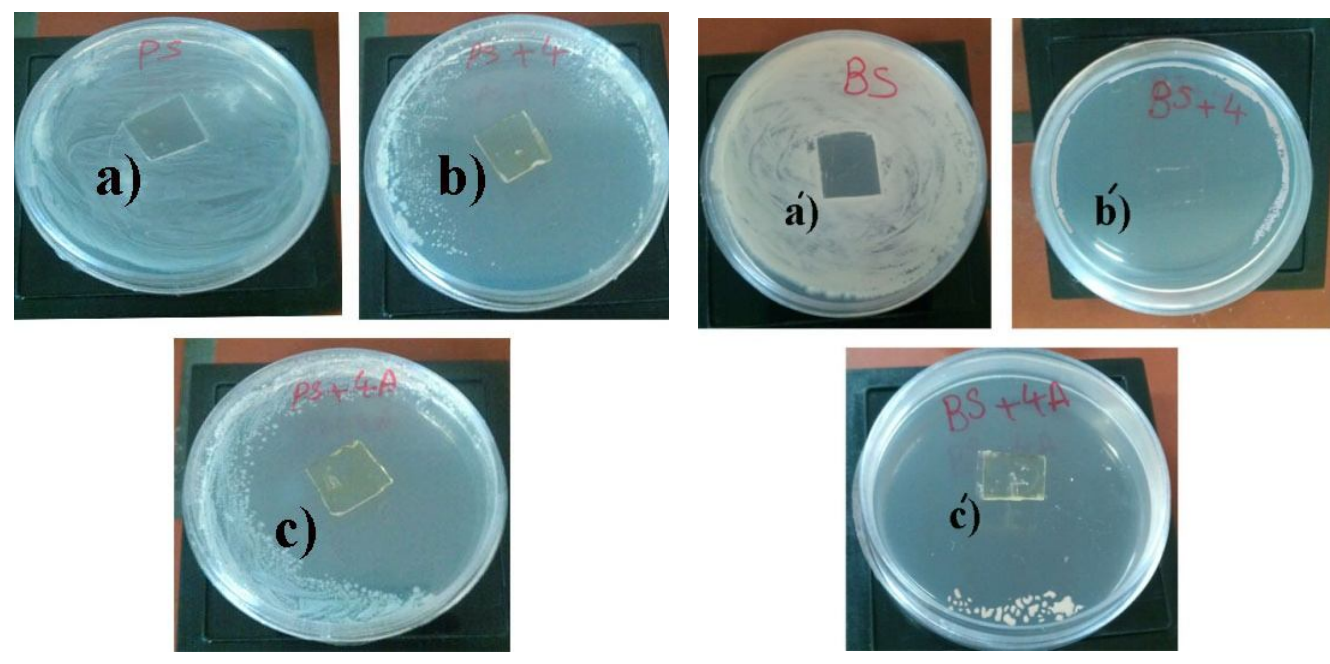

Figure3. Inhibition zones of (a) untreated glass slide; (b) treated glass slide with TAPP ${ }^{4+}$ and (c) treated glass slide with ZnTAPP ${ }^{4+}$ against $P$. aeruginosa. (a') untreated glass slide; (b') treated glass slide with TAPP ${ }^{4+}$ and (c') treated glass slide with $\mathrm{ZnTAPP}^{4+}$ against $P$. aeruginosa.

Percentage of photo-inactivation for both porphyrin compounds on the glass slides was $100 \%$ for two strains of bacteria at illumination time for $90 \mathrm{~min}$. Untreated control samples in the dark and under light irradiation allow bacterial growth. Porphyrin compounds induce singlet oxygen production; it is likely that this property imparts photo-bactericidal activity on $\mathrm{TAPP}^{4+}$ and $\mathrm{ZnTAPP}^{4+}$.

In the present study, photosensitive glass slides were successfully prepared by treating two tetra-cationic porphyrins onto glass slides. This suggests very interesting potentialities for further industrial applications.

These surfaces could be efficiently used in biomedical fields to prevent microbial infections.

\section{References:}

[1] Krouit M, Granet R, Krausz P, Photobactericidal Films from Porphyrins Grafted to Alkylated Cellulose Synthesis and Bactericidal Properties, European Polymer Journal, 45 (2009), 1250-1259.

[2] Roy D, Knapp JS, Guthrie JT, Perrier S, Antibacterial Cellulose Fiber via RAFT Surface Graft Polymerization, Biomacromolecules, 9 (2008), 91-99.

[3] Ringot C, Sol V, Barrière M, Saad N, Bressollier P, Granet R, Couleaud P, Frochot C, Krausz P, Triazinyl Porphyrin-based Photoactive Cotton Fabrics: Preparation, Characterization, and Antibacterial Activity. Biomacromolecules. 2011; 12: 1716-1723.

[4] Dosselli R, Tampieri C, Ruiz-González R, De Munari S, Ragàs X, Sánchez-García D, Agut M, Nonell S, Reddi E, Gobbo M, Synthesis, Characterization, and Photoinduced Antibacterial Activity of Porphyrin-Type Photosensitizers Conjugated to the Antimicrobial Peptide Apidaecin 1b. J.Med.Chem. 2013; 56: 1052-1063.

[5] Nitzan Y, Ashkenazi H, Photoinactivation of Acinetobacter Baumannii and Escherichia Coli B by a Cationic Hydrophilic Porphyrin at Various Light Wavelengths. Curr. Microbiol. 2001; 42: 408-414.

[6] Ergaieg K, Chevanne M, Cillard J, Seux R, Involvement of Both Type I and Type II Mechanisms in Grampositive and Gram-negative Bacteria Photosensitization by a Meso-substituted Cationic Porphyrin. Sol. Energy. 2008; 82: 1107-1117. 
[7] Benov L, Batinić-Haberle I, Spasojević I, Fridovich I, Isomeric N-alkylpyridylporphyrins and their Zn(II) complexes: inactive as SOD mimics but powerful photosensitizers. Arch. Biochem. Biophys. 2002; 402: 159165.

[8] Muñoz-Bonilla A, Fernandez-Garcia M, Polymeric materials with antimicrobial activity, Progress in Polymer Science. 2012; 37: 281-339.

[9] Grinholc M, Szramka B, Olender K, Graczyk A, Bactericidal Effect of Photodynamic Therapy Against Methicillin-resistant Staphylococcus aureus Strain with the Use of Various Porphyrin Photosensitizers. Acta Biochim. Pol. 2007; 54: 665-670.

[10] Cassidy CM, Donnelly RF, Tunney MM, Effect of Sub-lethal Challenge with Photodynamic Antimicrobial Chemotherapy ( PACT ) on the Antibiotic Susceptibility of Clinical Bacterial Isolates. J. Photochem. Photobiol. B. 2010; 99: 62-66.

[11] Parsons C, McCoy CP, Gorman SP, Jones DS, Bell SEJ, Brady C, McGlinchey SM, Anti-infective Photodynamic Biomaterials for the Prevention of Intraocular Lens-associated Infectious Endophthalmitis. Biomaterials. 2009; 30: 597-602.

[12] Xing C, Yang G, Liu L, Yang Q, Lv F, Wang S, Conjugated polymers for light-activated antifungal activity. Small. 2012; 8: 525-529.

[13] Banfi S, Caruso E, Buccafurni L, Battini V, Zazzaron S, Barbieri P, Orlandi V, Antibacterial Activity of Tetraaryl-porphyrin Photosensitizers: An in Vitro Study on Gram Negative and Gram Positive Bacteria. J. Photochem. Photobiol. B. 2006; 85: 28-38.

[14] Bozja, J, Yi K, Shafer WM, Stojiljkovic I. Porphyrin-based Compounds Exert Antibacterial Action Against the Sexually Transmitted Pathogens Neisseria Gonorrhoeae and Haemophilus Ducreyi. Int. J. Antimicrob. Agents. 2004; 24: 578-584.

[15] Ashkenazi, H, Nitzan Y, Gal D. Photodynamic Effects of Antioxidant Substituted Porphyrin Photosensitizers on Gram-positive and -negative Bacteria. Photochem. Photobiol. 2003; 77: 186-191.

[16] Spesia, MB, Lazzeri D, Pascual L, Rovera M, Durantini EN Photoinactivation of Escherichia Coli Using Porphyrin Derivatives with Different Number of Cationic Charges. FEMS Immunol. Med. Microbiol. 2005; 44: 289-95.

[17] Li, H, Fedorova OS, Grachev AN, Trumble WR, Bohach GA, Czuchajowski L (1997) A series of Mesotris (N-methyl-pyridiniumyl)-(4-alkylamidophenyl) Porphyrins: Synthesis, Interaction with DNA and Antibacterial Activity. Biochim. Biophys. Acta. 1354: 252-260.

[18] Krishnamurthy M, Synthesis and characterization of a new water-soluble porphyrin. Indian. J. Chem. 1977; 15B: 964-966.

[19] Thompson A, Krishnamurthy M, Peripheral charge effects on the kinetics of Zn(II)-porphyrin system. J. Inorg. Nucl. Chem. 1979; 41: 1251-1255.

[20] Rahimi R, Ph.D Dissertation, Howard University, 1992.

[21] Shamim A, Hambright P, An equilibrium and kinetic study of water-soluble cadmium porphyrins. Inorg. Chem. 1980; 19: 564-566. 